\title{
Measurement of hydraulic conductivity under horizontal paths in granular soils
}

\author{
Medición de la conductividad hidráulica bajo trayectorias horizontales en suelos granulares \\ Maria Fernanda García ${ }^{1}$, Camilo Andres Aldana ${ }^{2}$, Allex Fabrizio Lopez ${ }^{3}$, Juan Carlos Ruge-C.4*, Eliana Martinez-Rojas ${ }^{5}$ \\ IIngeniera Civil, mgarcia11@upc.edu.co, ORCID: 0000-0002-8301-9609, Universidad Piloto de Colombia, Bogotá, Colombia. \\ 2 Ingeniero Civil, caldana53@upc.edu.co, ORCID: 0000-0002-4733-1806, Universidad Piloto de Colombia, Bogotá, Colombia. \\ 3 Ingeniero Civil, alopez77@upc.edu.co, ORCID: 0000-0001-7603-6315, Universidad Piloto de Colombia, Bogotá, Colombia. \\ 4*Ph.D. en Geotecnia, juan.ruge@unimilitar.edu.co, ORCID: 0000-0002-9100-6058, Universidad Militar Nueva Granada, Bogotá, Colombia. \\ Ph.D en Ing. de Estructuras, Cimentaciones y Materiales, eliana-martinez@unipiloto.edu.co, ORCID: 0000-0002-5092-5920, Universidad Pilotode Colombia, \\ Bogotá, Colombia.
}

How to cite: M. García, C. Aldana, A. Lopez, J. Ruge and E. Martinez, "Measurement of hydraulic conductivity under horizontal paths in granular soils". Respuestas, vol. 24, no. 3, pp. 87-95, 2019.

Received on March 20, 2018 - Approved on July 17, 2018

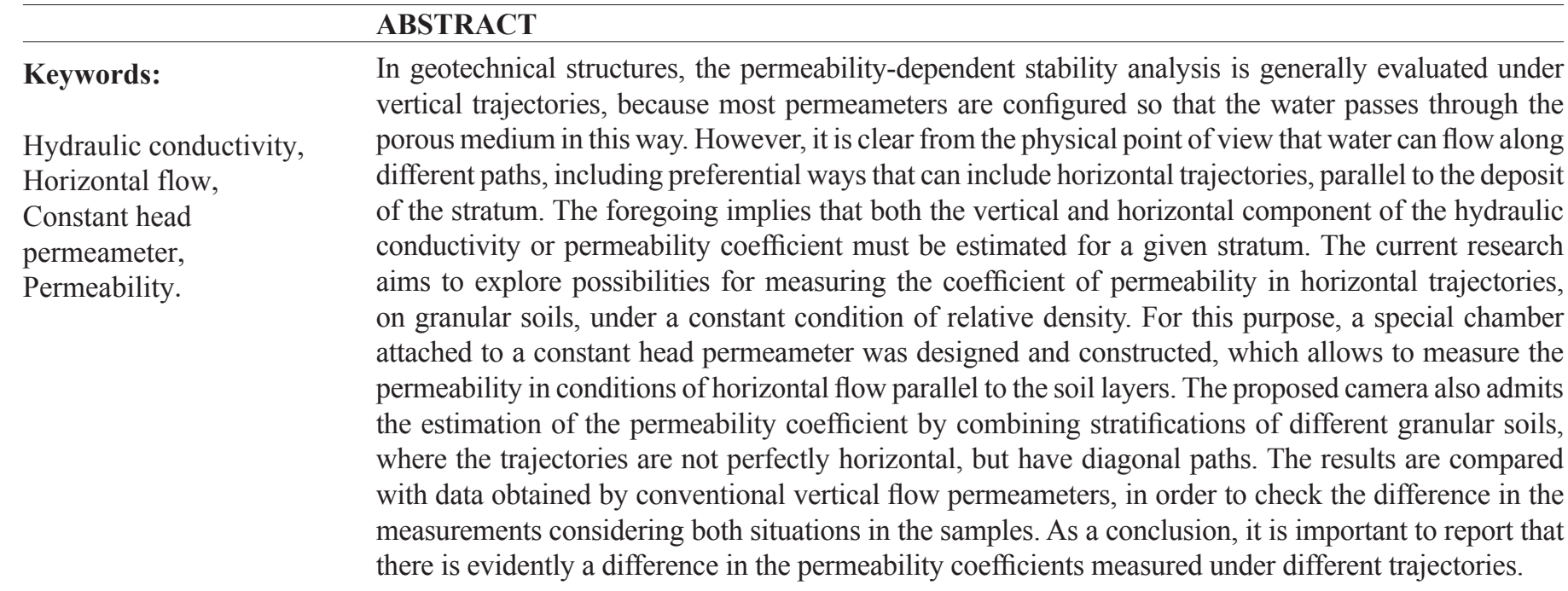

\section{RESUMEN}

\section{Palabras clave:}

Conductividad

hidráulica,

Flujo horizontal,

Permeámetro de

cabeza constante,

Permeabilidad.
En las estructuras geotécnicas generalmente el análisis de estabilidad dependiente de la permeabilidad, es evaluado bajo trayectorias verticales, debido a que la mayoría de permeámetros están configurados para que el agua atraviese de esta manera el medio poroso. No obstante, es claro desde el punto de vista físico que el agua puede fluir siguiendo diferentes caminos, entre ellos recorridos preferenciales que pueden incluir trayectorias horizontales paralelas a la depositación del estrato. Lo anterior implica que se debe estimar para un estrato, tanto la componente vertical, como horizontal de la conductividad hidráulica o coeficiente de permeabilidad. En la investigación actual se pretende explorar posibilidades de medición del coeficiente de permeabilidad en trayectorias horizontales, en suelos granulares, bajo una condición constante de densidad relativa. Para ello se diseñó y construyó una cámara especial adosada a un permeámetro de cabeza constante, que permite medir la permeabilidad en condiciones de flujo horizontal paralelo a los estratos. La cámara propuesta admite también, la estimación del coeficiente de permeabilidad combinando estratificaciones de diferentes suelos granulares, donde las trayectorias no son perfectamente horizontales, sino presentan recorridos diagonales. Los resultados son comparados con datos obtenidos mediante permeámetros convencionales de flujo vertical, con el fin de comprobar la diferencie en las mediciones considerando ambas situaciones en las muestras. Como conclusión generar es importante reportar que evidentemente existe una diferencia en los coeficientes de permeabilidad medidos bajo diferentes trayectorias.

*Corresponding author. 


\section{Introduction}

Although the phenomenon of permeability is widely studied within a conceptual framework, as observed in the current state of the art, because measurements of hydraulic conductivity are fully established for most porous materials. There are certain knowledge gaps that need to be filled. Among them, the estimation of the coefficient of permeability starts from different trajectories or preferential paths than the fluid (water), which has been theoretically evidenced, but empirical studies that demonstrate these distinctions are still scarce. For this reason, nowadays research based on estimating the permeability of a soil is directed to the application of modern theories to solve stochastically or numerically how it permeates water through a porous structure or in the research of new materials.

This research seeks by means of the design and construction of a special chamber, the measurement of the coefficient of permeability of granular soils considering different trajectories to the vertical, which has been during the time the standard parameter measured in most of the studies. The chamber will be adapted to an existing permeameter that uses the constant head method to induce water infiltration into the soil [1]. The samples were prepared for a constant void ratio, close to the minimum, in order to properly calibrate the chamber and be able to compare adequately with conventionally performed tests with permeability on vertical trajectories.

The trajectories through which water flows through a soil layer may be favored by factors such as gravity, soil stratification, hydraulic gradient, void ratio, among others. These previous aspects can influence that the water permeates through the porous medium by different roads and this not only prefers vertical trajectories, which have been the most used in the perme parameters constructed to date to estimate the coefficient of permeability based on Darcy's law.

In the process of soil formation and deposition, sedimentation generates anisotropy in the soil strata in several directions. Normally the permeability is calculated considering the flow in a uniform soil layer and without taking into account the direction of the flow perpendicular or parallel to this deposition.
However, the peripheral element (chamber) must comply with the same Darcy's physical principle in which the bases for calculating permeability are laid, even in state-of-the-art equipment such as Ksat for example. Therefore this must be able to measure a flow through a cross section of a selected soil. The equation that simulates this behavior has a proportionality constant that is considered the permeability coefficient and which is represented in terms of velocity $(\mathrm{cm} / \mathrm{s}$ or $\mathrm{m} / \mathrm{s})$.

Calculating with high reliability a parameter that physically simulates the behavior of a material is a challenge that has always been faced in the engineering of materials, geotechnical engineering does not escape this challenge. Today's permeameters are deficient in calculating permeability in paths other than vertical. The importance of calculating these trajectories is due to the fact that in situ the water drains into the soil in different directions, which is why only considering the vertical permeability within the calculation of a flow in a geotechnical structure is incorrect.

As mentioned above, the construction of an accessory to an existing permeameter will allow the academic and research community to understand water flow in porous media under different trajectories. This practice can be included within the content of the soil mechanics course, obeying the continuous updating within the current trends of self-evaluation and national and international accreditation.

The results evidenced the difference between the values obtained in conventional permeameters and the values estimated in the proposed chamber for the measurement of non-vertical trajectories (preferably horizontal).

\section{State of the art}

To understand the behavior of geotechnical problems, it is imperative to derive the implications of water flow through saturated soils. The establishment of constitutive functions that can relate water content and poro-water pressure is carried out by means of indirect permeability measurements [1]. The determination of the concept of permeability is a slow and substantially tedious process, in which two 
representative parameters predominate: the void ratio e and the moisture content w [2]. However, its value varies considerably from one soil to another, so it tries to correlate its behaviour with parameters that depend on constitutive models that are easy to determine. The first constitutive equations that related permeability to other measurable properties were based mainly on the assumption of uniform spherical granulometry to develop an ideal means of development [3].

There are different stochastic models that attempt to determine the behavior of the connections between pores [4], [5], in order to relate their structure to their means of communication. Therefore, two media that have the same void ratio may exhibit different permeabilities depending on pore size and number of pores. The more small pores there are, the lower the saturated permeability than a medium composed of fewer large pores. Each soil tissue comprises a geometrically abstract pore system that requires more than a particular characterization of its size by means of a distribution [6].

As specified in Darcy's equation, the coefficient of permeability $(\mathrm{Ks})$ quantifies the velocity function of water flow based on a given hydraulic gradient. Various models and empirical equations aim at structuring the permeability constant through easily accessible parameters or data [7] - [9], in order to establish a relationship between the concept of saturated hydraulic conductivity and the exchange between soils and atmosphere. In the literature, the classical constitutive models for estimating Ks usually include analytical extrapolations using the mean value of saturated hydraulic conductivity and the humidity-capillary head curve [10], [11].

Saturated permeability is a simple but critical mechanical-hydraulic property of soil that, unlike unsaturated permeability, does not require scaling of hydraulic conductivity when applied to a constituent pore model [12]. The concept of permeability is concatenated with a series of basic laws of flow in porous media as well as extrinsic constituents derived from adjacent saturations called tortuosity factors that appear in most constitutive equations and are described from the physical properties of the environment. To understand the actual dependence of permeability on the topological and geometric properties of porous tissue phenomenological functions have been developed [13], in these models the mass transfer coefficient and specific surface areas are quantified independently.

Cohesive soils are three-phase media because the variation in sizes and shapes in their microstructure is significant and evolves with changes in suction. There is a type of empirical formula for the permeability coefficient of saturated clay based on the fractal dimension [14]. This constitutive model is mainly based on the concept of percolation for the characterization of heterogeneous porous media [15]. The process of measuring permeability comprises a process dominated in particular by precepts already in place of vertical drainage. However, the understanding of this type of phenomenon is usually carried out by finite element modeling [16], which leads directly to the deformation calculation without the need for an emphasis on drainage analysis [17].

To explain the permeability parameter more realistically, some tests are performed on the basis of horizontal percolation, such devices can replace and be used in a plurality of situations in which the vertical chamber is compromised causing uncertainties during the application of a load [18]. Conventionally, anisotropy is referred to as the relationship between horizontal and vertical permeability, in which the calibration of parameters is done according to the prospective use of the soil body. The permeability of porous media is often expressed as a function of porosity, and is directly proportional to the void ratio.

Suction and degree of saturation influence stiffness, shear strength and pre-consolidation pressure. Therefore, for the mastery of these factors, the water retention property and the response to stress-strain trajectories, constitutive models based on the conceptual interpretation of saturated soils are idealized [19]. Ks modeling can be improved iteratively in a conventional two-phase model or with three-phase models coupled to two-phase flows, where the equations are solved simultaneously with the pressure balances.

The capillary model, the hydraulic model and the probabilistic models take into account the distribution of pore size over permeability 
[20]. However, because the structural mass is microscopically a porous medium composed of soil particles of different sizes, these models do not represent actual behavior, and vary in significance with stress-strain trajectories. Each component of a single pore distribution is representative of a specific suction curve [21], this theory has incidence in the prefiguration of a constituent archetype that relates both permeability and relative suction. The general concept of the theory of percolation was proposed by [22], to understand the stochastic field of random means linked to the network models that symbolize the porous tissue of the geotechnical volume, and that are complementary to the theory of filtration.

Some of the most important theoretical and empirical formulas for determining permeability [23] - [25], are successive transfigurations of observations and the premise of uniformity coefficient for variations of viscosity, specific surface and porosity through capillary tubes. As soil mechanics developed as a basin, each of the intrinsic parameters in it was adapted to practical quantitative situations between permeability indices and grain size distribution. The main objective of current methodologies has been to determine hydraulic conductivity by means of grain size distribution based on a single parameter: effective diameter [26]. With respect to cohesive soils, the pathology commonly found after infiltration flows is called internal erosion, where the critical gradient is expressed as a function of hydraulic shear [27]. Analytical solutions [28] present a new approach to this problem by trying to estimate, by means of simulations, the probability of random events through one-dimensional permeability.

Generally, Ks is quantified by constant head test for high permeability soils, and variable head for cohesive soils. These tests are based on Darcy's law, which is represented by an equation empirically derived through relative observations of percolation through granular soils, which holds that the discharge velocity is proportional to the hydraulic gradient and a coefficient of permeability [29].

Virtual simulations of laboratory tests have taken importance in the last decade with respect to the traditional tests to estimate the $\mathrm{Ks}$, where the measures necessarily present values of vertical net permeability. In situ tests to determine vertical diffusivity and horizontal transmissibility [30]], in which effective properties can be analyzed in both directions. To base this premise on practical acts, the assumption of isotropy in the horizontal plane is very common in permeability calculations for vertical wells, only that the vertical component in modelling is not entirely isotropic [31].

The spatial distribution of cohesive soils with respect to permeability follows variable contour modeling criteria for stationary two-dimensional flow in finite element constituent software such as [32], which is designed for nonlinear and linear stress analysis.

The mutual interaction of the phases of a soil is mainly due to the mechanical and hydraulic interaction of its various states, this type of coupling influences both the filtration capacity and the response to stresses in clay soils. Stress trajectories due to variations in permeability can be calculated using Terzaghi's one-dimensional consolidation theory [33]. The permeability coefficients of clays are controlled by variables that can be classified as mechanical and physicochemical, when Ks presents an abnormal behavior, this behavior is mainly attributed to high viscosity environments. There are several types of assumptions that can relate the permeability gradient to flow in a linearity dependence, which is generally valid when saturated clays have large Ks [34].

The pathologies of saturated soils induced by filtration can be projected on rigid wall permeameters [35], which study the relationship between effective stress and hydraulic gradient at the onset of failure. However, not only specialized mechanisms in percolation processes can quantify the calibration of constituent parameters; permeability tests with triaxial tests test saturated soils under in-situ conditions under effective stresses and equivalent pressures [36].

When applying the theory of correlation between permeability and other intrinsic parameters, it must be congruent in physical properties. Therefore, the devices controlling $\mathrm{Ks}$ in non-polar fluids must be mechanical. Several mechanical devices that are based on purposes other than the calculation 
of permeability, are archetypes for the modeling of Ks data, the Rowe cell performs consolidation tests in soils with low permeability, excluding the disadvantages presented by conventional consolidometers [37]. Due to the characteristics of the equipment, it is possible to carry out permeability tests under specific conditions of effective stress, which can be variable or constant.

\section{Materials and methods}

Since the essence of the project consists of the design, construction and proper commissioning of a dual chamber, for the calculation of the coefficient of permeability in granular soils under horizontal and vertical trajectories, it is crucial to ensure the quality of calibration tests of the materials used, as well as the calibration tests of the chamber.

\section{Characterization of materials}

By way of illustration, the camera houses two types of materials which are separated horizontally by means of a grid with a 200 sieve, in order to avoid the flow of material between the two materials. The selected granular soils are Guamo sand and Ottawa sand. Two materials commonly used in research works of this nature. As a consequence of the above, the basic characterization tests for the two sands are shown.

In Table 1, it is possible to analyze the two situations in terms of compactness conditions that the sands can be installed in the chamber, in this case the loose condition was used, which was achieved by carefully placing the material inside the chamber with a special tool to avoid its free fall. This type of test does not have a normative in the local context. However, it describes the procedure that should be the same used in the materials formed inside the chamber under similar conditions, because the calibration of the equipment should be done in the most appropriate way possible, to avoid disparity of criteria in terms of data analysis and results.

Table I. Loose and compact condition for the two sands in question

\begin{tabular}{|c|c|c|c|c|c|c|c|c|}
\hline \multicolumn{3}{|c|}{ loose condition } & \multicolumn{3}{|c|}{ guamo sand } & \multicolumn{2}{|c|}{ compacted condition } & \multirow{2}{*}{$\begin{array}{c}\text { average } \\
1,390\end{array}$} \\
\hline $\begin{array}{l}\text { density } \\
\left(\mathrm{g} / \mathrm{cm}^{3}\right)\end{array}$ & 1,309 & 1,301 & 1,300 & 1,303 & 1,392 & 1,398 & 1,378 & \\
\hline \multicolumn{9}{|c|}{ ottawa sand } \\
\hline \multicolumn{3}{|c|}{ loose condition } & \multicolumn{2}{|c|}{ average } & \multicolumn{3}{|c|}{ compacted condition } & average \\
\hline $\begin{array}{l}\text { density } \\
\left(\mathrm{g} / \mathrm{cm}^{3}\right)\end{array}$ & 1,324 & 1,330 & 1,314 & 1,323 & 1,402 & 1,404 & 1,400 & 1,402 \\
\hline
\end{tabular}

As for specific gravity, it was developed through INV E-128 "Determination of the specific gravity of solid particles in soils and mineral filler, using a pycnometer with water" (INVIAS, 2013). The results of the specific gravity for both granular materials are shown in Table 2.

Table 2. Specific gravity of materials used in the permeability chamber

\begin{tabular}{|c|c|c|c|c|c|c|c|}
\hline \multicolumn{2}{|c|}{ ottawa sand } & \multicolumn{2}{|c|}{ average } & \multicolumn{2}{|c|}{ guamo sand } & \multicolumn{2}{|c|}{ average } \\
\hline specific gravity 2,68 & 2,67 & 2,66 & 2,67 & 2,73 & 2,70 & 2,73 & 2,72 \\
\hline
\end{tabular}

As far as the particle size distribution is concerned, this was done following the INV E-123 standard "Determination of soil particle sizes". Naturally, as these are soils with almost $100 \%$ granular contents, only the part of the standard related to sieving was used (Figure 1). As can be seen, these materials are practically very similar in this respect, with slight differences in their smaller sizes.
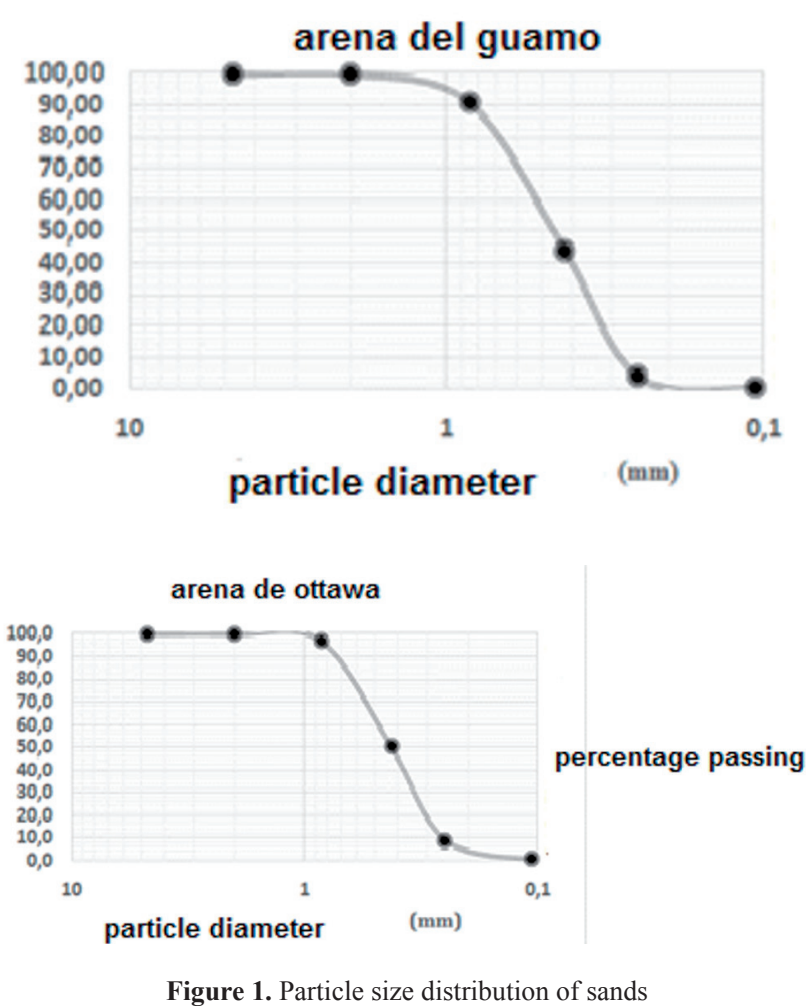

\section{Chamber construction and assembly}

The permeability chamber consists of four acrylic walls, which are attached to each other, using screws and ensuring that there are no water leaks between the joints. The inlet and outlet of the flow in both directions are guaranteed by valves and 
fittings placed in the acrylics. A small 200 mesh is inserted inside the fittings to avoid clogging and contamination of the hoses with particle dragging. Similarly, the connection for the piezometers is made in the same way as described on the walls of the chamber in order to guarantee the piezometric heights on the equipment panel (Figure 2). In the upper part of the sample a part of springs must be placed that fix the sieves No. 200 to the sample, to guarantee the correct flow of water and avoid any expansion of the material during saturation (Figure 3).

The chamber functions as peripheral equipment to an existing constant head permeameter, although with some variations it can function as stand-alone equipment.

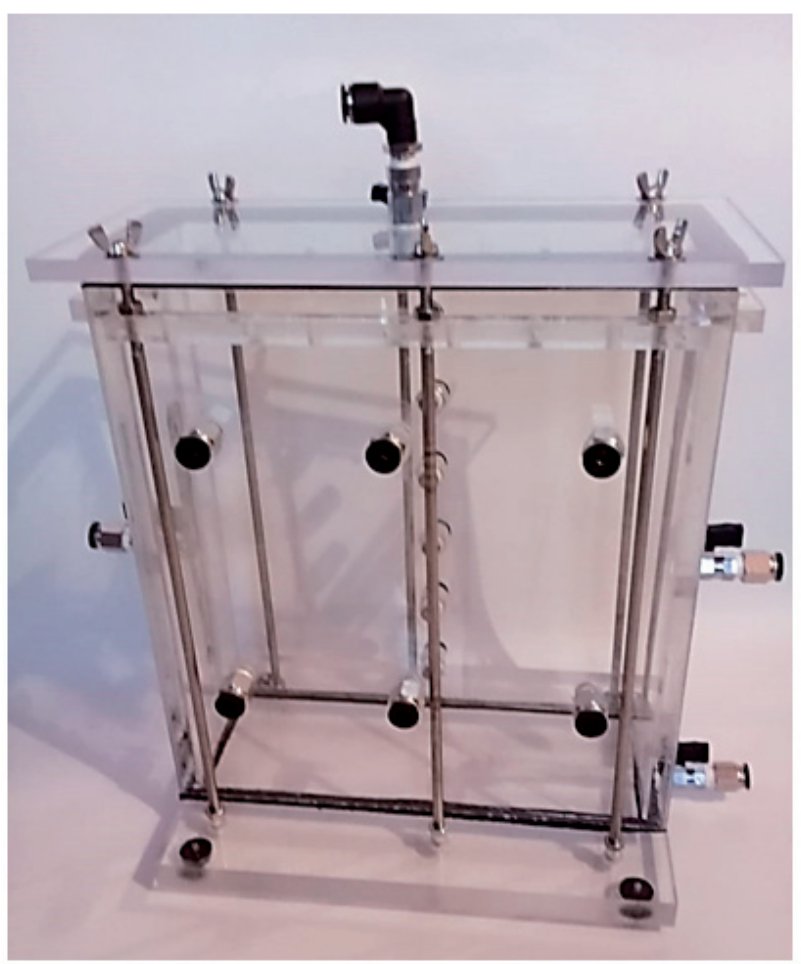

Figure 2. Assembled dual permeability chamber

The process ofinstalling the materials into the chamber involves a process of minimum compaction of the sample tending to set a minimum density, according to the values obtained in the characterization of materials. The two sands are separated by a 200 mesh, in order to prevent the dragging of particles and contamination of the samples placed in the chamber (See Figure 5).

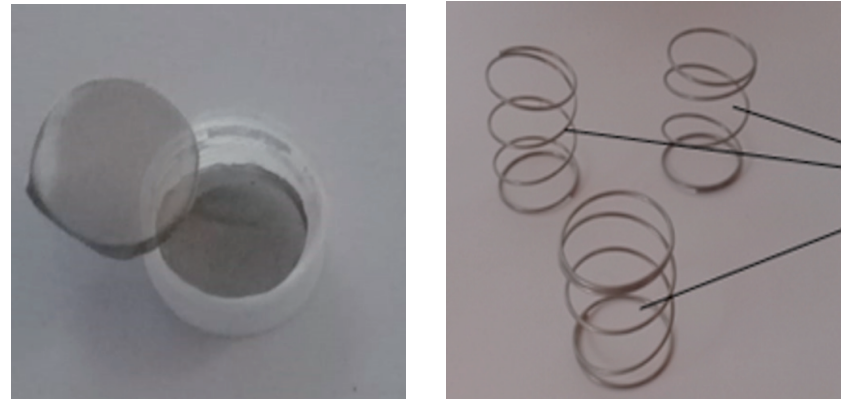

Figure 3. 200 mesh in the couplings and springs of the upper part of the chamber

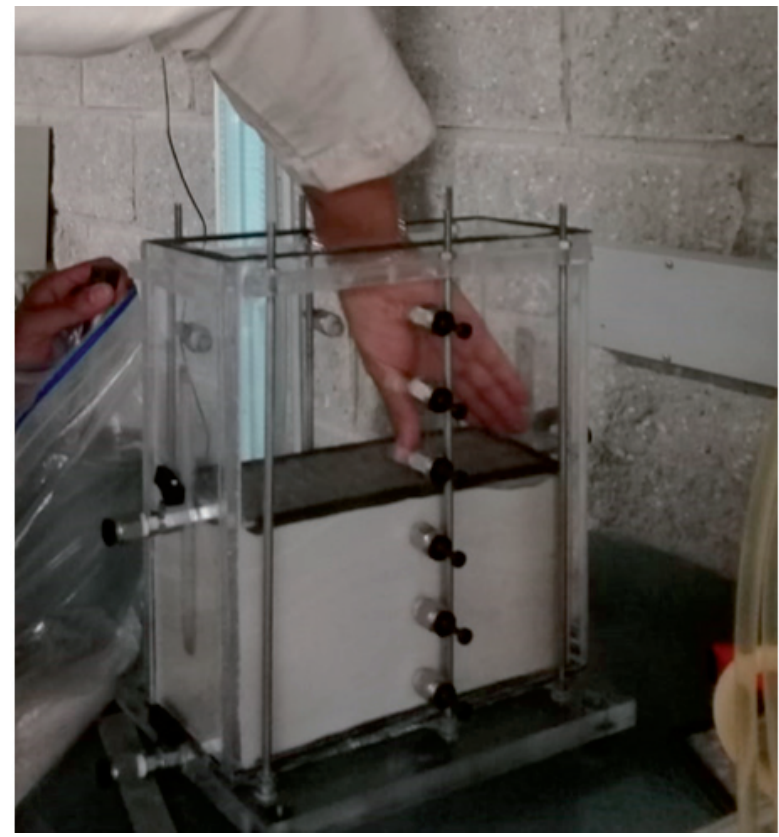

Figure 4. Positioning the 200 mesh between the sands

\section{Results and Discussion}

As indicated above, laboratory tests were carried out on all the materials, obtaining the permeability coefficients parallel (horizontal) and perpendicular (vertical) to the stratification, according to the layer configuration shown in Figure 6. Although the tests have some variations regarding the traditionality of the permeability tests, the INV E-130 standard "Permeability of granular soils (constant head)" was considered as the basis.

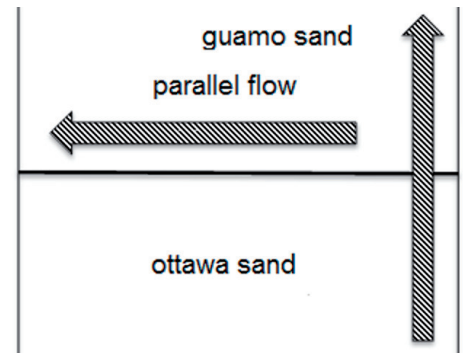

perpendicular flow

Figure 5. Strata Configuration and Water Flow 
The standard is naturally based on Darcy's law for the estimation of hydraulic conductivity or coefficient of permeability, for which the following equation was used.

$$
k=\frac{Q L}{A t h}
$$

Where $\mathrm{k}$ is the hydraulic conductivity (coefficient of permeability), Q is the flow rate, $\mathrm{L}$ is the distance between gauges, $\mathrm{A}$ is the cross-sectional area of the sample, $\mathrm{t}$ is the total drainage time and $\mathrm{h}$ is the head between gauges. Tests were performed for both trajectories in order to calibrate the constructed chamber. This calibration took into account the comparison with the state of the art, in terms of the values obtained. That is to say, that the estimation will yield reasonable data, referring to the ranges of material tested.

Table 3 shows the permeability coefficient calculations in perpendicular condition to the stratification posed in the chamber.

Table III. Permeability coefficients in trajectories perpendicular to the stratification

\begin{tabular}{|c|c|c|c|c|c|c|}
\hline rehearsal & volume of water & time & water temperature & \multicolumn{2}{|c|}{ manometers } & $\begin{array}{c}\text { coefficient of } \\
\text { permeability }\end{array}$ \\
\hline $\mathrm{N}^{\circ}$ & $\left(\mathrm{cm}^{3}\right)$ & $\mathrm{s}$ & $\left({ }^{\circ} \mathrm{C}\right)$ & $\mathrm{h} 1$ & $\mathrm{~h} 2$ & $(\mathrm{k})$ \\
\hline 1 & 840 & 30 & 19,30 & 102 & 34,0 & 0,007625272 \\
\hline 2 & 860 & 30 & 18,90 & 102 & 31,0 & 0,007476961 \\
\hline 3 & 860 & 30 & 19,00 & 102 & 29,7 & 0,007342520 \\
\hline 4 & 880 & 30 & 19,80 & 102 & 28,0 & 0,007340674 \\
\hline 5 & 900 & 30 & 19,20 & 102 & 22,0 & 0,006944444 \\
\hline
\end{tabular}

As can be seen in the results, the values obtained from the permeability coefficient present similar values to those reported in the DIN standard (Table 4), for a medium grain sand, which could be compatible with an average permeability coefficient when water permeates through the two sand layers. In this way, it can be corroborated that the resulting data are considered reasonable, within the state of the art.

Table IV. Hydraulic conductivity in soils (DIN 18130, 1998)

\begin{tabular}{|c|c|}
\hline $\begin{array}{c}\text { gravel } \\
\text { coarse sand } \\
\text { medium grain sand }\end{array}$ & $\begin{array}{c}10^{-1} \text { a } 10^{-2} \mathrm{~m} / \mathrm{s} \\
\text { Aprox. } 10^{-3} \mathrm{~m} / \mathrm{s} \\
10^{-3} \mathrm{a} 10^{-4} \mathrm{~m} / \mathrm{s}\end{array}$ \\
\hline fine-grained sand & $10^{-4} \mathrm{a} 10^{-5} \mathrm{~m} / \mathrm{s}$ \\
\hline silty sand & $10^{-5} \mathrm{a} 10^{-7} \mathrm{~m} / \mathrm{s}$ \\
\hline $\begin{array}{c}\text { silty clay } \\
\text { clay }\end{array}$ & $\begin{array}{c}10^{-6} \mathrm{a} 10^{-9} \mathrm{~m} / \mathrm{s} \\
<10^{-9} \mathrm{~m} / \mathrm{s}\end{array}$ \\
\hline
\end{tabular}

In relation to the trajectories parallel to the stratification, the data obtained by means of the camera are shown in Table 5.

Table V. Permeability coefficients in trajectories parallel to stratification

\begin{tabular}{|c|c|c|c|c|c|c|}
\hline \multirow{2}{*}{$\begin{array}{c}\text { rehersal } \\
\mathrm{N}^{\circ}\end{array}$} & \multirow{2}{*}{$\begin{array}{l}\text { volume of } \\
\text { water } \\
\left(\mathrm{cm}^{3}\right)\end{array}$} & \multirow{2}{*}{$\underset{\mathrm{s}}{\text { time }}$} & \multirow{2}{*}{$\begin{array}{c}\text { water } \\
\text { temperature } \\
\left({ }^{\circ} \mathrm{C}\right)\end{array}$} & \multicolumn{2}{|c|}{ manometer } & \multirow{2}{*}{$\begin{array}{l}\text { coefficient of } \\
\text { permeability } \\
\text { (k) }\end{array}$} \\
\hline & & & & h1 & $\mathrm{h} 2$ & \\
\hline 1 & 555 & 60 & 19,8 & 102 & 56 & 0,007447665 \\
\hline 2 & 549 & 60 & 20,1 & 102 & 56 & 0,007367150 \\
\hline 3 & 575 & 60 & 20,3 & 102 & 52 & 0,007098765 \\
\hline 4 & 570 & 60 & 19,2 & 102 & 52 & 0,007037037 \\
\hline 5 & 565 & 60 & 19,5 & 102 & 53 & 0,007117662 \\
\hline
\end{tabular}

Although a priori, it was considered that the permeability coefficients of the horizontal trajectories could be higher, due to the fact that the flow of water does not necessarily cross two strata, in the data obtained a parity of results is observed when comparing with vertical trajectories.

\section{Conclusions}

It was indeed proven that the dual chamber is suitable for estimating the hydraulic conductivity of granular materials, even when a stratification, in this case of two materials, is configured within the chamber. It is possible to install more layers of material in the chamber to calculate an equivalent coefficient of permeability of the whole.

Calculations of the coefficient of permeability obtained from the chamber are considered within the accepted ranges for this type of material. In this way, it is considered that the chamber has a correct construction and calibration.

The dual permeability chamber allows the calculation of the hydraulic conductivity under both proposed trajectories. This is extremely useful for understanding the behaviour of geotechnical-hydraulic structures where the flow under different trajectories can control the mechanical response of the material.

\section{Acknowledgements}

The authors are grateful to the Universidad Piloto de Colombia and the Universidad Militar Nueva Granada for the willingness of the soil laboratories for the development of this research. This paper is a result of the the IMP-ING-2932 funded by the Research Vice-Rectory of the Universidad Militar Nueva Granada. 


\section{References}

[1] C. Valencia and J. Triana "Diseño y construcción de un permeámetro para suelos granulares Trabajo de grado de pregrado", Universidad Piloto de Colombia, 2013.

[2] E. Leong and H. Rahardjo, "Permeability functions for unsaturated soils", Journal of geotechnical and geoenvironmental engineering, vol. 123, no. 12, pp. 1118-1126, 1997.

[3] D. Fredlund and H. Rahardjo, "Soil mechanics for unsaturated soils", John Wiley \& Sons, 1993.

[4] L. Weeks and S. Richards, "Soil- Water Properties Computed from Transient Flow Data 1", Soil Science Society of America Journal, vol. 31, no. 6, pp. 721-725, 1967.

[5] C. Juang and R. Holtz, "A probabilistic permeability model and the pore size density function", International Journal for numerical and analytical methods in geomechanics, vol. 10, no. 5, pp. 543- 553, 1986.

[6] I. Garcia-Bengochea, A. Altschaeffl and C. Lovell, "Pore distribution and permeability of silty clays", Journal of the Geotechnical Engineering Division, vol. 105, no. 7, pp. 839-856, 1979.

[7] E. Romero, A. Gens and A. Lloret, "Water permeability, water retention and microstructure of unsaturated compacted Boom clay", Engineering Geology, vol. 54, no. 1-2, pp. 117-127, 1999.

[8] J. Hyman, P. Smolarkiewicz and C. Larrabee, "Pedotransfer functions for permeability: a computational study at pore scales", Water Resources Research, vol. 49, no. 4, pp. 2080-2092, 2013.

[9] R. Chapuis and M. Aubertin, "On the use of the Kozeny Carman equation to predict the hydraulic conductivity of soils", Canadian Geotechnical Journal, vol. 40, no. 3, pp. 616-628, 2003.
[10] J. Bear, "Dynamics of fluids in porous media. Elsevier, New York. Dynamics of fluids in porous media", Elsevier, New York, 1972.

[11] Y. Mualem, "A new model for predicting the hydraulic conductivity of unsaturated porous media", Water resources research, vol. 12, no. 3, pp. 513-522, 1976.

[12] W. Brutsaert, "Some methods of calculating unsaturated permeability", Transactions of the ASAE, vol. 10, no. 3, pp. 400-0404, 1967.

[13] N. Burdine, "Relative permeability calculations from pore size distribution data", Journal of Petroleum Technology, vol. 5, no. 3, 71-78, 1953.

[14] J. Hyman, P. Smolarkiewicz and C. Larrabee, "Pedotransfer functions for permeability: a computational study at pore scales", Water Resources Research, vol. 49, no. 4, pp. 20802092. 2013.

[15] X. Zhang, M. Li, Y. Sun, Y. Zhu, Z. Yang and D. Tian, "Study on permeability coefficient of saturated cohesive soil based on fractal theory", IOP Conference Series: Earth and Environmental Science, vol. 242, no. 6, pp. 062055, 2019.

[16] E. Perrier, N. Bird and M. Rieu, "Generalizing the fractal model of soil structure: The poresolid fractal approach", Geoderma, vol. 88, no. 3-4, pp. 137-164, 1999.

[17] C. Hird, I. Pyrah and D. Russel, "Finite element modelling of vertical drains beneath embankments on soft ground", Geotechnique, vol. 42, no. 3, pp. 499-511, 1992.

[18] A. Britto and M. Gunn, "Critical state soil mechanics via finite elements", 1987.

[19] M. Roth, L. Caslake and S. FU, "Patent Application No. 16/175,346”, 2019.

[20] G. Vecchia, and E. Romero, "A fully coupled elastic-plastic hydromechanical model for compacted soils accounting for clay activity", International Journal for Numerical and 
Analytical Methods in Geomechanics, vol. 37, no. 5, pp. 503-535, 2013.

[21] C. Lapierre, S. Leroueil and J. Locat, "Mercury intrusion and permeability of Louiseville clay", Canadian Geotechnical Journal, vol. 27, no. 6, pp. 761- 773, 1990.

[22] P. Simms and E. Yanful, "Predicting soil-water characteristic curves of compacted plastic soils from measured pore-size distributions", Géotechnique, vol. 52, no. 4, pp. 269-278, 2002.

[23] B. Berkowitz and R. Ewing, "Percolation theory and network modeling applications in soil physics", Surveys in Geophysics, vol. 19, no. 1, pp. 23-72, 1998.

[24] A. Hazen, "Some physical properties of sands and gravels with special reference to their use in filtration", 24th Annual Report, Massachusetts State Board of Health, 1892.

[25] C. Slichter, "Theoretical investigation of the motion of ground waters", 19th Annual Reoort, U.S. Geological Survey, vol. 2, no. 305, 1899.

[26] K. Terzaghi, "Erdbaumechanik", Deuticke Vienna, pp. 120, 1925.

[27] M. Alyamani and Z. Şen, "Determination of hydraulic conductivity from complete grainsize distribution curves", Groundwater, vol. 31, no. 4, pp. 551-555, 1993.

[28] C. Hurtado, "Influencia del porcentaje de finos en la permeabilidad de materiales arenoarcillosos", Master's thesis, Universidad del Norte, 2018.

[29] Z. Lu and D. Zhang, “On importance sampling Monte Carlo approach to uncertainty analysis for flow and transport in porous media", Advances in Water Resources, vol. 26, no. 11, pp. 1177-1188, 2003.
[30] J. Jabro, "Estimation of saturated hydraulic conductivity of soils from particle size distribution and bulk density data", Transactions of the ASAE, vol. 35, no. 2, pp. 557-560, 1992.

[31] W. Burns Jr, "New single-well test for determining vertical permeability", Journal of petroleum technology, vol. 21, no. 6, pp. 743$752,1969$.

[32] H. Mukherjee and M. Economides, "A parametric comparison of horizontal and vertical well performance", SPE Formation Evaluation, vol. 6, no. 2, pp. 209-216, 1991.

[33] L. Börgesson, "Abaqus. In Developments in geotechnical engineering", Elsevier, vol. 79, pp. 565-570, 1996.

[34] G. Mesri and R. Olson, "Mechanisms controlling the permeability of clays", Clays and Clay minerals, vol. 19, no. 3, pp. 151-158, 1971.

[35] H. Olsen, "Hydraulic flow through saturated clays", Clays and Clay Minerals, vol. 9, no. 1, pp. 131-161, 1960.

[36] R. Moffat and R. Fannin, "large permeameter for study of internal stability in cohesionless soils", Geotechnical Testing Journal, vol. 29, no. 4, pp. 273-279, 2006.

[37] F. Tavenas, P. Leblond, P. Jean and S. Leroueil, "The permeability of natural soft clays. Part I: Methods of laboratory measurement", Canadian Geotechnical Journal, vol. 20, no. 4, pp. 629-644, 1983.

[38] J. Hidalgo, “Consolidación De Suelos Visco - Plásticos: generacion de presion de poro y deformaciones diferidas", Tesis de maestria En Ingeniería (Geotecnia). Universidad nacional autonoma de mexico, 2007. 